\title{
In Vitro Antibacterial Activity of an Aqueous Extracts of the Tephrosia Vogelii Hook.f Combined To Imipenem on E. coli Strains
}

Jean Fabrice Yala ${ }^{1 *}$, Rolande Mabika Mabika ${ }^{1}$, Franck Mounioko ${ }^{1}$, Ornella Zong Minko ${ }^{1}$, Alexis Nicaise Lepengue ${ }^{3}$, Alain Souza ${ }^{1,2}$

${ }^{1}$ Laboratory of Molecular and Cellular Biology, Bacteriology-Immunology Team, Agrobiology Research Unit, Masuku University of Science and Technology (USTM), BP 067 Franceville, Gabon

${ }^{2}$ Laboratory of Animal Physiology and Pharmacology, Agrobiology Research Unit, Masuku University of Science and Technology (USTM), BP 067 Franceville, Gabon

${ }^{3}$ Laboratory of Plant Physiology, Phytopathology and Plant Breeding, Agrobiology Research Unit, Masuku University of Science and Technology (USTM), BP 067 Franceville, Gabon

DOI: $10.36347 /$ sajp.2020.v09i01.008

| Received: 05.01.2020 | Accepted: 12.01.2020 | Published: 29.01.2020

*Corresponding author: Yala Jean Fabrice

Abstract

Original Research Article

Background: To investigate, In Vitro, the antibacterial properties of Tephrosia Vogelii and its effects when combined with imipenem and to assess the level of bacterial resistance to imipenem and colistin. Methods: Sensitivity to colistin and imipenem was evaluated by the determination of Minimum Inhibitory Concentrations (MIC) in accordance with the recommendations of the Antibiogram Committee of the French Society of Microbiology (CASFM). The sensitivity of Tephrosia Vogelii was evaluated by the diffusion method in the wells in agar medium; while, the combined effects of the latter with imipenem were evaluated by the determination of MIC. Results: The MIC results showed that 55\% of the E. coli strains are resistant to imipenem and $40 \%$ resistant to colistin. Tephrosia Vogelii has no antibacterial activity on $E$. coli strains. In addition, its association with imipenem led to the potentiation of the antibacterial activity of imipenem with a synergistic effect. Conclusion: The results may justify the use of the plant-antibiotic conventional combination against bacterial resistances to conventional antibiotics.

Keywords: Escherichia coli, carbapenem, colistin, Tephrosia Vogelii.

Copyright @ 2020: This is an open-access article distributed under the terms of the Creative Commons Attribution license which permits unrestricted use, distribution, and reproduction in any medium for non-commercial use (NonCommercial, or CC-BY-NC) provided the original author and source are credited.

\section{INTRODUCTION}

The development and rapid spread of antibiotic resistance currently observed is a worldwide concern. Antibiotics are natural substances produced by certain microorganisms, or synthetic products to defend against other microorganisms. They are generally used in case of infectious diseases from bacteria [1]. However, several bacteria have developed resistance mechanisms with several causes including high drug pressure because of anarchic prescription by hospital systems and self-medication. This massive use of antibiotics contributes to the development of acquired and natural resistances to the antibiotics [2]. As a consequence, many therapeutic failures are reported around the world [3].

Infantile diarrhea is reported as the second cause of death for children under 5 years of age worldwide with nearly 1.7 billion cases per year, or 525,000 deaths per year of children under 5 , with 80 per cent mortality in Africa and South Asia [2]. Indeed, the literature emphasizes that the prevalence of diarrheal diseases is $22.1 \%$ for the North-Central region of Morocco, $15.8 \%$ in Burkina Faso, and $19.1 \%$ in the Central regions of Malawi [4], 18\% in the Democratic Republic of Congo [5] and $18.9 \%$ for Cameroon [6]. In Gabon, the incidence of diarrheal diseases remains poorly documented. Nevertheless, some studies show that the prevalence of diarrhea varies through regions, with a very high rate in large cities such as Libreville and Port-Gentil with $17.5 \%$ compared to other cities in the country with $13.9 \%$ [7]. However, more recent studies revealed that the prevalence of diarrheal diseases in the whole country was $15.8 \%$ [8]. In addition, a recent study on the infectious etiologies of childhood diarrhea conducted in Gabon, especially in the province of Ogooue-Lolo revealed that Escherichia coli was considered ass one of the most reliable agent [9]. The same study revealed also that these strains of $E$. coli had a high rate of carbapenem resistant (75\%). This resistance is heterogeneous depending on the molecule used: Ertapenem (100\%), Doripenem (100\%), 
Meropenem (60\%) and Imipenem (40\%) [10]. These results are a great concern because carbapenems are the last line of defense against multidrug-resistant bacterial infections (MRB) [10].

Facing carbapenem resistance, colistin, belonging to the polymyxin family is another antibiotic mostly recommended. However, we are seeing the emergence of colistin-resistant strains with a frequency of 1.2\% between 2011-2015 in humans distributed between E. coli and Klebsiella pneumoniae, respectively $1.4 \%$ and $0.7 \%$ [11].

With considerable growth of traditional antibiotic resistance, a plethora of alternatives solutions are needed. One of them could be find in medicinal plants usually used in traditional therapy. Indeed, the use of plant species for therapeutic purposes has gained a tremendous importance and the demand for medicinal plant-based raw materials is growing at the rate of 15$25 \%$ annually. In addition, several studies show that plant extracts have large diversity of chemical structures and also a very wide range of active principles derived from them [12].

Tephrosia Vogelii Hook.f, (T. Vogelii), is a legume plant (Fabaceae), itchyotoxic [13], traditionally used for fishing [13]. It presents several biological activities including entomological activities [14], antifungals [15], anticancer [16] and antibacterial properties [17]. Moreover, with the need for alternatives treatments against some severe infectious diseases, the use of many combinations of antibiotics is required to optimize the spectrum of action of antibiotics in one hand [1], in other hand, a combination of antibiotics with plant extracts may be use because this kind of combinations may be reliable to reduce bacterial resistance to antibiotics [18].

The present work aimed to study the antibacterial activity of $T$. Vogelii combined with imipenem on $E$. coli strains isolated from infantile diarrhea. A phytochemical screening of the plant leaves extract was performing first.

\section{MATERIAL AND METHODS Microbial Material}

In this study we used a total of twenty strains of Escherichia coli (E. coli) isolated from infantile diarrhea feces at the Paul Moukambi Regional Hospital Center in Koula-Moutou. All analyses were performed in the Laboratory of Molecular and Cellular Biology (LABMC) of the University of Science and Technology of Masuku.

\section{Preparation of Bacterial Pre-Cultures}

From cryopreserved stocks of 20 E. coli strains isolated infantile diarrhea feces, $10 \mu \mathrm{l}$ were removed and then seeded by streaking method on BHI agar. The dishes were incubated at $37^{\circ} \mathrm{C}$ for $18-24 \mathrm{~h}$. Young colonies $18-24 \mathrm{~h}$ obtained were used for the preparation of inoculi.

\section{Inoculation Preparation}

The inoculi were prepared from $18-24 \mathrm{~h}$ precultures. To do this, one to two colonies of the mother culture were removed and diluted in sterile tubes containing $3 \mathrm{ml}$ of physiological saline $(0.9 \% \mathrm{NaCl})$. The optical density was read using a spectrophotometer (UNICO, Italy) at a wavelength of $625 \mathrm{~nm}$. The optical densities measured ranged from 0.08 to 0.132 ; which corresponds to a density of $0.5 \mathrm{Mac}$ Farland and is equivalent to a bacterial load of $1.510^{8} \mathrm{CFU} / \mathrm{ml}$ for the evaluation of the activity of the antibiotics, while for the evaluation of the activity of the plant extracts, they ranged from 0.06 to 0.08 ; which corresponds to a density of 0.3 Mac Farland and is equivalent to a bacterial load of $1.10^{6} \mathrm{CFU} / \mathrm{ml}$.

\section{Evaluation of the sensitivity of $E$. coli strains to antibiotics}

\section{Determination of the Minimal Inhibitory} Concentration (MIC) of imipenem and colistin

The evaluation of the sensitivity of $E$. coli by the liquid microdilution method was used to determine the minimum inhibitory concentrations (MIC) of imipenem and colistin.

A range of dilutions of the geometric concentrations of reason $2(0.25-32 \mu \mathrm{g} / \mathrm{ml})$ of imipenem and colistin were made from a stock solution concentrated at $128 \mu \mathrm{g} / \mathrm{ml}$. The controls were prepared by adding $200 \mu \mathrm{l}$ of BHI culture medium for the negative control, and $100 \mu \mathrm{l}$ of BHI medium added to $100 \mu \mathrm{l}$ of the bacterial suspension for the positive control. Finally, the microplates were incubated at $37^{\circ}$ $\mathrm{C}$ for 18-24h. Each test was reproduced three times and the interpretation was made according to CAFSM recommendations 2017.

Phytochemical Screenig and Evaluation of the
Antibacterial Activity of Tephrosia Vogelii Hook.f
Plant Material
The plant material consisted of leaves of Tephrosia Vogelii Hook.f, (T. Vogelii). The young leaves of T. Vogelii were harvested at Benguia village 2 (latitude -1.63236, longitude 13.4918) in the town of Franceville. After harvest, the leaves were dried for three days out of the sun in an oven. The dried leaves obtained were crushed using an electrical apparatus (Blender MXGX161, Panasonic, USA) until a fine powder was obtained.

\section{Phytochemical Screening}

Phytochemical screening revealed the composition of secondary metabolites present in young T. Vogelii leaves. 
Thus, $5 \mathrm{~g}$ of the plant material powder was mixed with $250 \mathrm{ml}$ of sterile distilled water, and then the mixture was boiled for 15 minutes. The decoction obtained was filtered using cotton, then for each test, 2 $\mathrm{ml}$ of the filtrate were used.

Phytochemical tests of the aqueous extracts of T. Vogelii leaves were carried out according to the conventional techniques described.

\section{Test for Saponins}

Two milliliters $(2 \mathrm{ml})$ of the aqueous extract of plant were transferred in a test tube and the tube was shaked vigorously. 5 minutes later, the presence of persistent moss highlights the presence of Saponins.

\section{Test for Tannins}

Two milliliters $(2 \mathrm{ml})$ of the aqueous extract were transferred to a test tube, then $2 \mathrm{ml}$ of $1 \%$ iron trichloride $\left(\mathrm{Fecl}_{3}\right)$ was added. The observation of a greenish or blackish blue color indicates the presence of tannins.

\section{Test for Polyphenols}

Two milliliters $(2 \mathrm{ml})$ of the aqueous extract were transferred to a test tube, then $1 \mathrm{ml}$ of Follin Ciocalteux reagent and $1 \mathrm{ml}$ of sodium bicarbonate $\left(\mathrm{Na}_{2} \mathrm{CO}_{3}\right)$ were successively added. The observation of a dark green color indicates the presence of polyphenols.

\section{Test for Flavonoids}

Two milliliters $(2 \mathrm{ml})$ of the aqueous extract were transferred to a test tube, then $1 \mathrm{ml}$ of hydrochloric acid $(\mathrm{HCl})$ and $1 \mathrm{ml}$ of sodium bicarbonate $\left(\mathrm{Na}_{2} \mathrm{CO}_{3}\right)$ were successively added. The appearance of an accent color was characteristic of the presence of flavonoids.

\section{Test for Alkaloids}

Alkaloids were identified by Mayer's reagent. The addition of a few drops of this reagent to $2 \mathrm{ml}$ of the extract solution leads to the formation of an orangered or greenish precipitate in the presence of the alkaloids.

\section{Test for Anthracene Compounds}

Two milliliters $(2 \mathrm{ml})$ of the aqueous extract were transferred to a test tube, and then $2 \mathrm{ml}$ of ammonia $\left(\mathrm{NH}_{4} \mathrm{OH}\right)$ were added. The observation of a red color indicates the presence of anthracenic compounds.

\section{Test for Sterols/Terpenes}

Two milliliters $(2 \mathrm{ml})$ of the aqueous extract were transferred to a test tube, and then $2 \mathrm{ml}$ of sulfuric acid $\left(\mathrm{H}_{2} \mathrm{SO}_{4}\right)$ were added. The observation of a red brown or purple ring indicates the presence of sterols or terpenoids.

\section{Test of Cardiotonic Glycoside Compounds}

Two milliliters $(2 \mathrm{ml})$ of the aqueous extract were transferred to a test tube, then $1 \mathrm{ml}$ of sulfuric acid $\left(\mathrm{H}_{2} \mathrm{SO}_{4}\right)$ and $1 \mathrm{ml}$ of ferric sulfate $\left(\mathrm{Fe}_{2} \mathrm{SO}_{4}\right)$ were added successively.

The observation of a dirty red color indicates the presence of digitoxin, a fluorescent red color indicates the presence of digitoxigenin, a yellow color then turns blue red indicates that the extract contains gitoxin, and the yellow coloring then turning purple red shows that the extract contains gitoxigenin.

\section{Determination of Polyphenols, Flavonoids and Total Tannins}

The purpose of the assay was to quantify chemical groups with pharmacological properties, particularly the polyphenols, flavonoids and total tannins contained in $T$. Vogelii leaves. The quantification was conducted as described by Ngoua Meye-Misso [19]. For a better evaluation, each test was reproduced three times.

\section{Total Polyphenols}

Two hundred microliters $(200 \mu \mathrm{l})$ of the aqueous extract of $T$. Vogelii leaves were transferred to a test tube, then $1 \mathrm{ml}$ of Follin Ciocalteux reagent and $800 \mu \mathrm{l}$ of sodium bicarbonate $\left(\mathrm{Na}_{2} \mathrm{CO}_{3}\right)$ were successively added. After homogenization, the tubes were incubated for 30 minutes and the reading of the optical density was made at the Biomate spectrophotometer (ThermoFisher Walthman, MA, USA) at a wavelength of $765 \mathrm{~nm}$. The concentration was established on the basis of the polyphenol equation of reference $=\mathrm{Y}=0.012 \mathrm{X}+0.0004$.

\section{Total Flavonoids}

One milliliter $(1 \mathrm{ml})$ of the aqueous extract was transferred to a test tube, and then $1 \mathrm{ml}$ of aluminum trichloride $\left(\mathrm{AlCl}_{3}\right)$ was added. After homogenization, the tubes were incubated for 10 minutes and the reading of the optical density was made at the Biomate spectrophotometer (ThermoFisher Walthman, MA, USA) at a wavelength of $435 \mathrm{~nm}$. The concentration was established on the basis of the flavonoid reference equation $\mathrm{Y}=0.0032 \mathrm{X}+0.0077$.

\section{Total Tannins}

Two hundred and fifty microliters $(250 \mu \mathrm{l})$ of the aqueous extract were transferred to a test tube, followed by $250 \mu \mathrm{l}$ of ferric ammonium, then $250 \mu \mathrm{l}$ of ammonia and $1250 \mu \mathrm{l}$ of distilled water were added respectively. The obtained solution was homogenized and incubated for 10 minutes and the reading of the optical density was made with the Biomate spectrophotometer (ThermoFisher Walthman, MA, USA) at a wavelength of $525 \mathrm{~nm}$. The concentration was established on the basis of the tannin reference equation $\mathrm{Y}=0.0009 \mathrm{X}+0.2088$. 
Determination of the antibacterial activity of leaves of Tephrosia Vogelii Hook.f, Aqueous extraction

Seventy-five grams (75 g) of powder of leaf were dissolved in $750 \mathrm{ml}$ of sterile distilled water and macerated for 24 hours with magnetic stirring at 750 $\mathrm{rpm} /$ minute at room temperature. The macerate subsequently obtained is subjected to a double hydrophilic cotton filtration and filtering with whatman $\mathrm{N}^{\circ} 1$ filter paper. The filtrate obtained was then lyophilized at $-42^{\circ} \mathrm{C}$. for 72 hours with a freeze-dryer of the Labconco Freezone type. 74200. The lyophilizates were stored at $4^{\circ} \mathrm{C}$ until use.

\section{Determination of the antibacterial activity of the extract}

The antibacterial activities of the aqueous extract of $T$. Vogelii young leaves were evaluated by the well diffusion method in agar. The modified $\mathrm{MH}$ agar at $10 \%$ was seeded by the flooding method with $2 \mathrm{ml}$ of bacterial inoculants of opacity 0.3 Mac Farland, then the Petri dishes were dried for 15 minutes. Then, wells were made in the agar. Finally, $50 \mu \mathrm{l}$ of the extract at concentrations of 50 and $100 \mathrm{mg} / \mathrm{ml}$ were placed in the wells, and the dishes were incubated at $37^{\circ} \mathrm{C}$. for 18 24h. The inhibition zones obtained were measured using calipers (Mitutoyo, Japan). Each test was repeated three times.

\section{Detention of Minimal Inhibitory Concentration (MIC) extracts}

The evaluation of the sensitivity of $E$. coli by the liquid microdilution method was used to determine the minimum inhibitory concentrations (MICs) of $T$. Vogelii. A range of geometric dilutions of reason 2 $(0.19-12.25 \mathrm{mg} / \mathrm{ml})$ were made from solutions of $T$. Vogelii extracts of $50 \mathrm{mg} / \mathrm{ml}$ and $100 \mathrm{mg} / \mathrm{ml}$. The controls were prepared by adding $100 \mu \mathrm{l}$ of BHI culture medium and $100 \mu \mathrm{l}$ of the solution of the aqueous extract of T. Vogelii leaves for the negative control, and $100 \mu \mathrm{l}$ of BHI medium added to $100 \mu \mathrm{l}$ of the bacterial suspension for the positive control. Finally, the microplates were incubated at $37^{\circ} \mathrm{C}$ for $18-24 \mathrm{~h}$. Each test was repeated three times.

\footnotetext{
Determination of the effect of the combination of Tephrosia Vogelii Hook.f, and imipenem

To determine the effect of the combination of imipenem and Tephrosia Vogelii Hook.f, on Escherichia coli strains, stock solutions of Tephrosia Vogelii Hook.f, and imipenem of concentrations 256 $\mu \mathrm{g} / \mathrm{ml}$ have been prepared. The test solution was derived from the mixing of the two stock solutions, and was used for liquid and solid-state tests.
}

Evaluation of the Minimal Inhibitory Concentration (MIC) of the association Tephrosia Vogelii Hook.f, and imipenem

The effect of the combination of imipenem and Tephrosia Vogelii Hook.f on E. coli strains coli was evaluated by the determination of minimum inhibitory concentrations (MIC) of this combination by the liquid microdilution method.

A range of geometric dilutions of reason 2 $(0.25$ to $32 \mu \mathrm{g} / \mathrm{ml})$ of the combination of imipenem and Tephrosia Vogelii Hook.f was made from a solution concentrated at $128 \mu \mathrm{g} / \mathrm{ml}$. The controls were prepared by adding $100 \mu \mathrm{l}$ of $\mathrm{BHI}$ culture medium and $100 \mu \mathrm{l}$ of the associative solution for the negative control, and $100 \mu \mathrm{l}$ of $\mathrm{BHI}$ medium added to $100 \mu \mathrm{l}$ of the bacterial suspension for the positive control. Finally, the microplates were incubated at $37^{\circ} \mathrm{C}$ for $18-24 \mathrm{~h}$. The determination of the type of effect was made on the basis of the report:

$$
\boldsymbol{\delta}_{\mathrm{CMI}}=\mathrm{CMI}_{\text {association }} / \mathrm{CMI}_{\text {imipénème }}
$$

If $1 / 2<\boldsymbol{\delta}_{\mathrm{CMI}} \leq 1 / 4$ : indifference effect, if $1 / 4<\boldsymbol{\delta}_{\mathrm{CMI}} \leq 1 / 8$ : addition effect, if $\boldsymbol{\delta}_{\mathrm{CMI}}<1 / 8$ : synergistic effect.

\section{STATISTICAL ANALYZES}

The statistical analyzes were performed on the Excel 2010 software, and on the $\mathrm{R}$ version 3.2.2 software, at the significance level of 0.05 . The $R$ software allowed us to perform the Anova test which was used to compare the differences between the Minimum Inhibitory Concentrations (MIC) obtained from one bacterial strain to another for the imipenem, the association of Tephrosia Vogelii Hook.f with Imipenem and also, the difference between the diameters of inhibitions obtained from one bacterial strain to another one. The Excel software allowed to perform successively the Pearson and KHI 2 tests which were used to quantify the phytochemical groups.

\section{RESULTS \\ Determination of Minimal Inhibitory Concentration (MIC) at Imipenem \\ The results in Table- 1 show a variability of the} MIC of the imipenem as a function of the strain of $E$. coli tested. Indeed, the MICs are between 4 and 20 $\mu \mathrm{g} / \mathrm{ml}$. The highest MIC $(20 \pm 8 \mu \mathrm{g} / \mathrm{ml})$ is recorded with strain $\mathrm{EC}_{19}$ as well as the lowest $(4 \pm 0 \mu \mathrm{g} / \mathrm{ml})$ with strain $\mathrm{EC}_{17}$. In addition, the Anova test highlights a significant difference between the 20 strains of $E$. coli tested and MICs recorded with $\mathrm{P}=4.05 .10^{-11}$. 
Table-1: The different MICs of $E$. coli.

\begin{tabular}{|l|l|l|}
\hline & \multicolumn{2}{|l|}{ MIC Imipenem $(\mu \mathrm{g} / \mathrm{ml})$} \\
\hline Stains & & Phenotype \\
\hline $\mathrm{EC}_{1}$ & $6 \pm 2,3$ & I \\
\hline $\mathrm{EC}_{2}$ & $6 \pm 2,3$ & I \\
\hline $\mathrm{EC}_{3}$ & $12 \pm 4,6$ & $\mathbf{R}$ \\
\hline $\mathrm{EC}_{4}$ & $8 \pm 0,0$ & I \\
\hline $\mathrm{EC}_{5}$ & $8 \pm 0,0$ & I \\
\hline $\mathrm{EC}_{6}$ & $10 \pm 4,0$ & $\mathbf{R}$ \\
\hline $\mathrm{EC}_{7}$ & $8 \pm 0,0$ & $\mathbf{I}$ \\
\hline $\mathrm{EC}_{8}$ & $12 \pm 4,6$ & $\mathbf{R}$ \\
\hline $\mathrm{EC}_{9}$ & $10 \pm 6,9$ & $\mathbf{R}$ \\
\hline $\mathrm{EC}_{10}$ & $6 \pm 2,3$ & I \\
\hline $\mathrm{EC}_{11}$ & $6 \pm 2,3$ & I \\
\hline $\mathrm{EC}_{12}$ & $14 \pm 4,0$ & $\mathbf{R}$ \\
\hline $\mathrm{EC}_{13}$ & $\mathrm{Ind} \pm 0,0$ & $\mathbf{R}$ \\
\hline $\mathrm{EC}_{14}$ & $12 \pm 4,6$ & $\mathbf{R}$ \\
\hline $\mathrm{EC}_{15}$ & $12 \pm 4,6$ & $\mathbf{R}$ \\
\hline $\mathrm{EC}_{16}$ & $10 \pm 4,0$ & $\mathbf{R}$ \\
\hline $\mathrm{EC}_{17}$ & $4 \pm 0,0$ & I \\
\hline $\mathrm{EC}_{18}$ & $8 \pm 5,7$ & I \\
\hline $\mathrm{EC}_{19}$ & $20 \pm 8,0$ & $\mathbf{R}$ \\
\hline $\mathrm{EC}_{20}$ & $10 \pm 6,9$ & $\mathbf{R}$ \\
\hline
\end{tabular}

Ind: indeterminate for a concentration $>32 \mu \mathrm{g} / \mathrm{ml}$; C: concentration; S: sensitive; R: resistant; I: intermediate; Imipenem: $\mathrm{S} \leq 2 \mathrm{mg} / \mathrm{ml} ; \mathrm{I}<2-8 \mathrm{mg} / \mathrm{ml} ; \mathrm{R}>8 \mathrm{mg} / \mathrm{ml}$.

\section{Evalaution of the sensitivity of $E$. coli with colistin}

The results in Table 2 reveal that the 20 strains of Escherichia coli have a phenotype of resistance to colistin at $32 \mu \mathrm{g} / \mathrm{ml}$, with a resistance prevalence of
40\%. Also, the Anova test suggests a significant difference $\left(\mathrm{P}=1.42 .10^{-44}\right)$ between diameters of inhibitions from one strain to another.

Table-2: Inhibition diameters of the 20 strains of $E$. coli with colistin.

\begin{tabular}{|c|c|c|c|}
\hline & CMI de la & & \\
\hline Strains & $\mathrm{C}(\mu \mathrm{g} / \mathrm{ml})$ & Phenotype & Percentage of resistance \\
\hline $\mathrm{EC}_{1}$ & $0,25 \pm 0,0$ & $\mathbf{S}$ & \multirow[t]{20}{*}{$\mathbf{4 0 \%}$} \\
\hline $\mathrm{EC}_{2}$ & $0,25 \pm 0,0$ & $\mathbf{S}$ & \\
\hline $\mathrm{EC}_{3}$ & $0,25 \pm 0,0$ & $\mathbf{S}$ & \\
\hline $\mathrm{EC}_{4}$ & $0,25 \pm 0,0$ & $\mathbf{S}$ & \\
\hline $\mathrm{EC}_{5}$ & $0,25 \pm 0,0$ & $\mathbf{S}$ & \\
\hline $\mathrm{EC}_{6}$ & $0,25 \pm 0,0$ & $\mathbf{S}$ & \\
\hline $\mathrm{EC}_{7}$ & $0,25 \pm 0,0$ & $\mathbf{S}$ & \\
\hline $\mathrm{EC}_{8}$ & $0,25 \pm 0,0$ & $\mathbf{S}$ & \\
\hline $\mathrm{EC}_{9}$ & $8 \pm 0,0$ & $\mathbf{R}$ & \\
\hline $\mathrm{EC}_{10}$ & $3 \pm 1,0$ & $\mathbf{R}$ & \\
\hline $\mathrm{EC}_{11}$ & $0,25 \pm 0,0$ & $\mathbf{S}$ & \\
\hline $\mathrm{EC}_{12}$ & $1,5 \pm 0,0$ & $\mathbf{S}$ & \\
\hline $\mathrm{EC}_{13}$ & Ind $\pm 0,0$ & $\mathbf{R}$ & \\
\hline $\mathrm{EC}_{14}$ & $3 \pm 1,0$ & $\mathbf{R}$ & \\
\hline $\mathrm{EC}_{15}$ & $3 \pm 1,0$ & $\mathbf{R}$ & \\
\hline $\mathrm{EC}_{16}$ & $16 \pm 0,0$ & $\mathbf{R}$ & \\
\hline $\mathrm{EC}_{17}$ & $6 \pm 2,0$ & $\mathbf{R}$ & \\
\hline $\mathrm{EC}_{18}$ & $0,625 \pm 0,4$ & $\mathbf{S}$ & \\
\hline $\mathrm{EC}_{19}$ & $1,5 \pm 0,5$ & $\mathbf{S}$ & \\
\hline $\mathrm{EC}_{20}$ & $8 \pm 0,0$ & $\mathbf{R}$ & \\
\hline
\end{tabular}




\section{Phytochemical Screening of Tephrosia Vogelii} Hook.f,

The results in Table- 3 show the composition of secondary metabolites present in the aqueous extract of the leaves of Tephrosia Vogelii Hook.f. The phytochemical screening revealed the presence of some chemical compounds such as saponins, tannins, polyphenols, flavonoids, alkaloids, cardiotonic heterosides, sterols and terpenes. The less abundant chemical groups being alkaloids followed by sterols and terpenes.

Table-3: Composition of secondary metabolites extracted from $T$. Vogelii leaves

\begin{tabular}{|l|l|}
\hline \multicolumn{2}{|c|}{ Yong leaves } \\
\hline Saponins & +++ \\
\hline Tannins & +++ \\
\hline Polyphenols & +++ \\
\hline Flavonoids & +++ \\
\hline alkaloids & ++ \\
\hline Anthracene & - \\
\hline Sterols/Terpenes & + \\
\hline cardiotonic Heterosides & +++ \\
\hline
\end{tabular}

+++: Very abundant; ++: abundant; +: trace; -: absent

Determination of polyphenols, flavonoids and total tannins

The results in Table-4 highlighted the concentrations in polyphenols, flavonoids and in tannins from young leaves of $T$. Vogelii. The Higher concentrations were obtained with the total tannins (1060.775 $\pm \mathrm{mg}$ TEA/mg of extract), followed by total flavonoids (924.625 $\pm \mathrm{mg} \mathrm{EQ} / \mathrm{mg}$ of extract) and total polyphenols (179.77 $\pm \mathrm{mg}$ AGE/mg extract).

Table-4: Concentration of polyphenols, flavonoids and total tannins in T. Vogelii leaves.

\begin{tabular}{|l|l|}
\hline Metabolic compounds & Aqueous extract of young leaves \\
\hline CPT (mg AGE/mg of extract) & $125.67 \pm 0,7$ \\
\hline CFT (mg QE/mg of extract) & $924.625 \pm 63,4$ \\
\hline CTT (mg ATE/mg of extract) & $1060.775 \pm 140,6$ \\
\hline
\end{tabular}

$\mathrm{CTP}=$ contenu phénolique total, $\mathrm{CFT}=$ contenu flavonoïde total, $\mathrm{CTT}=$ contenu tanin total, $\mathrm{AGE}=$ acide gallique équivalent, $\mathrm{QE}=$ quercétine équivalent, $\mathrm{ATE}=$ acide tannique équivalent

Evaluation of the sensitivity and determination of the MIC of Tephrosia Vogelii Hook.f,

The results in Table-5 show that the aqueous extracts of the young leaves of $T$. Vogelii did not exert any antibacterial activity on the Escherichia coli strains tested at concentrations of 50 and of $100 \mathrm{mg} / \mathrm{ml}$. In addition, the MICs were higher than the maximum concentration used $(25 \mathrm{mg} / \mathrm{ml})$.

Table-5: Results of the antibacterial activity of aqueous extract of Tephrosia Vogelii Hook.f.

\begin{tabular}{|l|l|l|}
\hline \multicolumn{3}{|c|}{ Young leaves } \\
\hline Strains & Diameters (mm) & MIC (mg/ml) \\
\hline $\mathrm{EC}_{1}$ & $0 \pm 0,0$ & $>25 \pm 0,0$ \\
\hline $\mathrm{EC}_{2}$ & $0 \pm 0,0$ & $>25 \pm 0,0$ \\
\hline $\mathrm{EC}_{3}$ & $0 \pm 0,0$ & $>25 \pm 0,0$ \\
\hline $\mathrm{EC}_{4}$ & $0 \pm 0,0$ & $>25 \pm 0,0$ \\
\hline $\mathrm{EC}_{5}$ & $0 \pm 0,0$ & $>25 \pm 0,0$ \\
\hline $\mathrm{EC}_{6}$ & $0 \pm 0,0$ & $>25 \pm 0,0$ \\
\hline $\mathrm{EC}_{7}$ & $0 \pm 0,0$ & $>25 \pm 0,0$ \\
\hline $\mathrm{EC}_{8}$ & $0 \pm 0,0$ & $>25 \pm 0,0$ \\
\hline $\mathrm{EC}_{9}$ & $0 \pm 0,0$ & $>25 \pm 0,0$ \\
\hline $\mathrm{EC}_{10}$ & $0 \pm 0,0$ & $>25 \pm 0,0$ \\
\hline $\mathrm{EC}_{11}$ & $0 \pm 0,0$ & $>25 \pm 0,0$ \\
\hline $\mathrm{EC}_{12}$ & $0 \pm 0,0$ & $>25 \pm 0,0$ \\
\hline $\mathrm{EC}_{13}$ & $0 \pm 0,0$ & $>25 \pm 0,0$ \\
\hline $\mathrm{EC}_{14}$ & $0 \pm 0,0$ & $>25 \pm 0,0$ \\
\hline $\mathrm{EC}_{15}$ & $0 \pm 0,0$ & $>25 \pm 0,0$ \\
\hline $\mathrm{EC}_{16}$ & $0 \pm 0,0$ & $>25 \pm 0,0$ \\
\hline $\mathrm{EC}_{17}$ & $0 \pm 0,0$ & $>25 \pm 0,0$ \\
\hline $\mathrm{EC}_{18}$ & $0 \pm 0,0$ & $>25 \pm 0,0$ \\
\hline $\mathrm{EC}_{19}$ & $0 \pm 0,0$ & $>25 \pm 0,0$ \\
\hline $\mathrm{EC}_{20}$ & $0 \pm 0,0$ & $>25 \pm 0,0$ \\
\hline
\end{tabular}


Jean Fabrice Yala et al., Sch Acad J Pharm, Jan, 2020; 9(1): 36-45

Evaluation of the MIC of Tephrosia Vogelii Hook.f combined with imipenem and their effects

The results of the Table 6 revealed a significant decrease in the MIC from the combination of the different substances which varies from 0.5-2 $\mu \mathrm{g} /$ $\mathrm{ml}$, compared to that of imipenem whose concentration range was from $4 \mu \mathrm{g} / \mathrm{ml}$ to $32 \mu \mathrm{g} / \mathrm{ml}$. While the MIC of the extract was greater than $25 \mathrm{mg} / \mathrm{ml}$. The Anova test showed that this decrease in the MIC was extremly significant $(\mathrm{p}<0.001)$.

Table-6: Results of MIC imipenem, extract of $T$. Vogelii and those of the imipenem combined with extract of $T$.

Vogelii.

\begin{tabular}{|l|l|l|l|}
\hline \multicolumn{3}{|c|}{ MIC $(\boldsymbol{\mu g} / \mathbf{m l})$} \\
\hline Souches d'E. coli & Imipenem & Plant extract* & Imipenem combined with plant extract \\
\hline EC1 & 6 & 25000 & 0,5 \\
\hline EC2 & 6 & 25000 & 0,5 \\
\hline EC3 & 12 & 25000 & 0,5 \\
\hline EC4 & 8 & 25000 & 0,5 \\
\hline EC5 & 8 & 25000 & 2 \\
\hline EC6 & 10 & 25000 & 0,5 \\
\hline EC7 & 8 & 25000 & 0,5 \\
\hline EC8 & 12 & 25000 & 0,5 \\
\hline EC9 & 10 & 25000 & 0,5 \\
\hline EC10 & 6 & 25000 & 0,5 \\
\hline EC11 & 6 & 25000 & 0,5 \\
\hline EC12 & 14 & 25000 & 0,75 \\
\hline EC13 & 32 & 25000 & 1 \\
\hline EC14 & 12 & 25000 & 0,5 \\
\hline EC15 & 12 & 25000 & 0,75 \\
\hline EC16 & 10 & 25000 & 1 \\
\hline EC17 & 4 & 25000 & 1 \\
\hline EC18 & 8 & 25000 & 0,5 \\
\hline EC19 & 20 & 25000 & 0,5 \\
\hline EC20 & 10 & 25000 & 0,5 \\
\hline & $*$ MIC of the plant extract $>25 \mathrm{mg} / \mathrm{ml}\left(25.10^{3} \mu \mathrm{g} / \mathrm{ml}\right)$ \\
\hline
\end{tabular}

\section{DISCUSSION}

This study aimed to determine, In Vitro, the antibacterial activity of Tephrosia Vogelii Hook.f, as well as the effect of its association with imipenem on twenty strains of Escherichia coli $($ E. coli) isolated from infantile diarrhea feces. These bacterial strains are well known to be resistant to carbapenem [9]. In addition, their sensitivity to colistin, an antibiotic recommended for the treatment of carbapenem-resistant Gramnegative bacilli infections [20], was studied.

The results show a prevalence of resistance of Escherichia coli to colistin of $40 \%$. This prevalence was higher than that observed in many studies estimated to, $6.91 \%$ and $6.2 \%[11,20]$. The high prevalence obtained with colistin in our study could be explained by the modification of the charges of the outer membrane of E. coli influencing the electrostatic interactions between the positive charges of colistin and the negative charges of the outer membrane of E. coli. Indeed, these changes are due the alteration of lipopolysaccharides (LPS) by covalent modifications of lipid A with the addition of phosphoethanolamine (PEtN) and 4-amino-4-deoxy-L-arabinose (L-Ara4N) on the phosphate groups of the lipid A [21] and by acylation/deacylation [22]. These covalent modifications neutralize the negative charges of lipid A, thus conferring resistance to colistin. In addition, some authors revealed that colistin-resistant Acinectobacter baumannii strains adopted different morphologies and topographies of sensitive cells [23].

Also, plasmid coexistence of $m c r-1 / 2$ genes and those involved in carbapenem resistance [20, 24] would induce the strong resistance to colistin obtained. The same $m c r-1$ gene encodes an enzyme that changes the charge carried by a region of LPS that becomes less sensitive to colistin [20, 24]. Clearly, it appeared that the plasmid carrying the $\mathrm{mcr}$ gene was first described in E. coli isolates in China [11].

In addition, the presence of colistin resistance genes on mobile genetic elements poses a serious public health risk favoring the rapid horizontal distribution of these genes [25]. Furthermore, previous studies have shown a link between the emergence of the $\mathrm{mcr}$ gene in patients, animals and the environment [26]. This suggests that the environment could be the source of contamination because it contains a bacterial mixture creating a selective pressure which favors the expansion of genes for antibiotic resistance [24]. The great use of colistin in the veterinary field is also responsible for the selection of bacteria resistant to colistin in the environment. In general, resistance to colistin has been 
shown in the Enterobacteriaceae family [27]. This resistance, which was only found in bacterial strains isolated from animals, has now been found in clinical and environmental strains.

The results of the phytochemical screening of the aqueous extract of the young leaves of Tephrosia Vogelii Hook.f, revealed the presence of saponins, tannins, polyphenols, flavonoids, alkaloids, cardiotonic glycosides. A study conducted on extracts of the olive tree showed that tannins and flavonoids inhibited the growth of E. coli, S. aureus, P. aeruginosa, Klebsiella pneumoniae and Salmonella typhi [28]. Flavonoids act through the inhibition of the fate [29]. Another wors, conducted on the antibacterial activity of 11 flavonoids revealed that 5 flavonoids inhibited the growth of $E$. coli by stiffening the membrane. Both the polymethoxyflavones and isoflavonoids increased the membrane fluidity [30]. However, young leaves of $T$. Vogelii do not contain the anthracene compounds.

Our results are not in accordance with findings observed in Congo which showed that $T$. Vogelii leaves contained saponins, polyphenols and steroids but not alkaloids, terpenoids and cardiotonic glycosides [16]. In Abomey Calavi, T. Vogelii leaves contained only catechol tannins, saponins, polyterpenes and sterols [31]. However, our results are similar with findings by some authors in Rwanda [32]. These qualitative variations in secondary metabolites would be the consequence of geospatial and temporal variation, climate, soil type, but also the condition and type of the organ used for the tests. They could also be attributable to the solvent used as shown elsewhere [33]. In this study, the authors showed that the total polyphenol quantity of Noé's $M$. deserti leaves was 184, respectively; 171; 133; 34 and $17 \mathrm{mg}$ EAG /100 g for methanol, water, n-butanol, dichloromethane and petroleum ether.

The quantitative study of the three main secondary metabolites (polyphenols, flavonoids, and total tannins) reveals high concentrations of these metabolites in the aqueous extract of young $T$. Vogelii leaves. Similar results were recorded with the ethanolic and hydroethanolic extracts of the leaves of Erythrophleun ivorense, in contrast, total polyphenol and flavonoids concentrations were low with the ethanolic and hydroethanolic and aqueous extracts of the fruits of Megaphrinium macrostachyum [19]. These results are due to the qualitative and quantitative heterogeneity of the presence of these metabolites in the different organs of the plant and solvent used [19, 33]. In addition, young leaves and apical parts often have the highest concentrations of secondary substances than other parts of the plant because of the higher photosynthetic activity in young leaves that contain high levels of chlorophyll [34].
The evaluation of Tephrosia Vogelii Hook.f extract showed no antibacterial activity despite the fact that some families of this group are a pharmacological interest. These results are similar to those of other works showing that the hydroalcoholic extract of $T$. Vogelii has activity only on Gram positive bacteria [17]. This lack of activity would be due to a decrease in the membrane permeability leading to the blockage of the crossing of the biological membranes therefore the lack of accessibility of the intracellular pharmacological target but also by reducing the concentration of the secondary metabolites [1]. It would also be dependent on a modification of the target by the bacteria [35] or the latter would actively kill the metabolites by activating the pumps would contribute to the loss of antibacterial activity of the aqueous extract of $T$. Vogelii Hook.f. [36]. Moreover, the colistin resistance mechanisms put in place by $E$. coli, by lipid A modification of LPS [21] present on the surface of Gram-negative bacteria with the $m c r 1$ gene could also be involved in the absence of observed activity.

The combined effect from imipenem and $T$. vogelli extract revealed a synergistic effect whereby antibacterial activity of extended-spectrum of imipenem on E. coli strains is improved by $T$. Vogelii extract. These results are supported by several studies in which the authors revealed that plant extracts would improve antibacterial activity of many antibiotics [1] and could allow the eradication of certain bacteria resistant to these antibiotics administered alone in treatment. Indeed, the combination of imipenem with the essential oil of Origanum majorana L. had a synergistic effect on E. coli (ATCC 25921), P. aeruginosa (ATCC 27853), $P$. aeruginosa, $S$. enteritidis and $P$. putida both disc that of $C$. coranarium $\mathrm{L}$ with ticarcillin had a synergistic effect with $E$. coli (ATCC 25921), K. pneumoniae, $P$. mirabilis and $S$. aureus [1]. In contrast, interactions of antibiotics and plant extracts have shown additive effects on $S$. aureus strains using the well diffusion method while they are synergistic when the liquid microdilution method is used [18]. These results could be explained by an increase in membrane permeability [1] whose consequences would be the release and greater accessibility of fixation sites by the antibiotic [37]. Also, it may cause both the action of secondary metabolites, including the action of tannins through their emulsifying activities will act by disintegration of the membrane, and facilitated the action of carbapenems, increasing their intracellular concentrations would allow more binding abundant with penicillin binding proteins, contributing to the inhibition of peptidoglycan synthesis [38]. Moreover, the mode of action of the combinations are significantly different from those of the molecules acting individually [39]. The synergistic effect obtained between imipenem and Tephrosia Vogelii Hook.f extract could lead to new options for the treatment of infectious diseases [18, 39]. Studies on the molecular basis of the synergistic interaction between $T$. Vogelii 
Jean Fabrice Yala et al., Sch Acad J Pharm, Jan, 2020; 9(1): 36-45

phytomolecules and imipenem would be needed to better explain and develop pharmacological agents to treat bacterial infections with medicinal plants $[1,40]$.

Overall, the use of antibiotics associated with plant extracts would be an alternative approach to cope with the strong emergence of bacterial resistance to antibiotics in prophylactic and curative therapies.

\section{CONCLUSION}

The purpose of this study was to demonstrate In Vitro the antibacterial properties of Tephrosia Vogelii Hook.f, and its effects in combined with imipenem on Escherichia coli strains isolated from infantile diarrhea feces. Although the aqueous extract of $T$. Vogelii revealed the presence of tannins, polyphenols, flavonoids, alkaloids, sterols and cardiotonic glycosides. We did not find any inhibitory activity on $E$. coli strains, but when we combined extract of T. Vogelii and imipenem, we showed an improvement of imipenem activity. Moreover, the present study with encouraging preliminary results highlighted the necessity to use an association between plant and antibiotic for therapeutic purposes. This may represent a potential pathway for drugs discovery allowing to overcome the increasing phenomena of bacterial resistance to conventional antibiotics. However, further studies are required which have to be focused on:

- Elucidation the mechanisms put in place during this potentiation of the activity of imipenem by Tephrosia Vogelii.

- Evaluation the toxicity of this combination for humans.

- Broadening the range of bacterial strains.

\section{REFERENCES}

1. Moussaoui F, Alaoui T. Evaluation of antibacterial activity and synergistic effect between antibiotic and the essential oils of some medicinal plants. Asian Pacific Journal of Tropical Biomedicine. 2016 Jan 1;6(1):32-7.

2. OMS. Activité de de l'OMS dans la région Africaine 2016-2017. 2017.

3. Yala JF, Mabika RM, Bisseye C, Kenguele H, Kama EM, Dikoumba AC. Phenotypic and genotypic characterization of extended-spectrumbeta-lactamases producing-Enterobacteriaceae (ESBLE) in patients attending Omar Bongo Ondimba military hospital at Libreville (Gabon). Current Research in Microbiology and Biotechnology. 2016;4(6):944-9.

4. Ebolowa Ngwe E, Banza-nsungu AB. Les déterminants socio-environnementaux de la morbidité diarrhéique des enfants de moins de 5 ans en milieu urbain au Cameroun: les villes d'Ebolowa et Maroua. Yaounde; 2007.

5. Atokare A. Facteurs explicatifs de la enfants de moins de cinq ans au Tchad Thème de mémoire : Facteurs explicatifs de la morbidité diarrhéique chez les enfants de moins de cinq ans au Tchad. Mémoire Online,. 2008.

6. Nguendo Yongsi B. Morphologie des terrains et maladies diarrhéiques à Yaoundé (Cameroun) : un essai de géomorphologie médicale en milieu urbain tropical. Rev Can Géographie Trop Can J Trop Geogr. 2014;1(2):24-36.

7. Minko Mi-Etoua MH. Les facteurs explicatifs de la morbidité diarrhéique des enfants de moins de cinq ans au Gabon. Yaoundé; 2008.

8. Nzame Vierin Y, Mengue M'Ella M, Ngoubeyou M, Moussavou A. Prise en Charge Pré Hospitalière de la Diarrhée chez l'Enfant de Moins de 5 Ans à Libreville Pre hospital management of diarrhea in children under 5 in Libreville. Heal Sci Dis. 2015;16(4):1-4.

9. Mabika Mabika R, Oyegue Liabagui LS, Mounioko F, Moussavou MG, Affiri Odzame JM, Souza A. Study of the sensitivity to Carbapenems in the Escherichia coli isolated from childhood diarrhea at the Paul Moukambi Hospital Center of Koula-Moutou. Int J Innov Sci Res. 2019;8(6):1411-7.

10. Nordmann P. Résistance aux carbapénèmes chez les bacilles à Gram négatif. Médecine/Sciences. 2010;26:950-9.

11. Liu YY, Wang Y, Walsh TR, Yi LX, Zhang R, Spencer J, Doi Y, Tian G, Dong B, Huang X, Yu LF. Emergence of plasmid-mediated colistin resistance mechanism MCR-1 in animals and human beings in China: a microbiological and molecular biological study. The Lancet infectious diseases. 2016 Feb 1;16(2):161-8.

12. Yala JF, Ntsameso-Mve-Mba V, Azzizet Issembe Y, Lepengue AN, Souza A. Évaluation In Vitro de l'activité antimicrobienne de l'extrait aqueux d'Eryngium foetidium récolté dans la ville de Franceville. J Appl Biosci. 2016;103:9886-93.

13. Ibrahim B, M'batchi B, Mounzeo H, Bourobou HB, Posso P. Effect of Tephrosia Vogelii and Justicia extensa on Tilapia nilotica in vivo. Journal of ethnopharmacology. 2000 Feb 1;69(2):99-104.

14. Akpo AA, Chougourou DC. Etude de L'efficacité de L'extrait des Feuilles de Tephrosia Vogelii Hook. f Pour le Contrôle de an. Gambiaes. 1 Résistant aux Pyréthrinoïdes. 2017;146(4):433-43.

15. Nziengui Nziengui A. Lutte contre la pourriture de la Roselle au Gabon: effet de quelques extraits vegetaux aqueux sur la croissance de Phoma sabdariffae Sacc. 2017.

16. Dianzitoukoulou Matsima LD. Etude de l'activité antiproliférative de Tephrosia Vogelii sur Saccharomyces cerevisiae. Mémoire Master/Université Marien NGOUABI/Congo. 2008. 55 p.

17. Anthoney ST, Obey JK, Terer E, Miyogo EO. In Vitro antibacterial activity of ethanolic-aqua extract of Tephrosia Vogelii bark against laboratory strains of selected microorganismes. Barat Interdiscip Res J, 2015;5:133-9. 
18. Adwan G, Mhanna M. Synergistic Effects of Plant Extracts and Antibiotics on Staphylococcus aureus Strains Isolated from Clinical. Middle-East J Sci Res. 2008;3(3):134-9.

19. Cédric SO, Joseph-Privat O, Louis-Clément OE, Guy-Stéphane P, Cheikna Z, Jean-Bernard BO, Emvo N, Edouard TA. Phytochemical screening, evaluation of antioxidant and antimicrobial properties of Erythrophleum ivorense A. Chev (Leguminosae) and Megaphrynium macrostachyum Benth (Marantaceae), medicinal plants from Gabon. Int. J. Biosci. 2016;8(6):43-53.

20. Wang R, van Dorp L, Shaw LP, Bradley P, Wang Q, Wang X, Jin L, Zhang Q, Liu Y, Rieux A, Dorai-Schneiders T. The global distribution and spread of the mobilized colistin resistance gene mcr-1. Nature communications. 2018 Mar 21;9(1):1179.

21. Falagas ME, Rafailidis PI, Mattahaiou DK. Resistance to polymyxins: Mechanisms, frequency and treatment options. Drug Resist Updat. 2010;13(4):132-8.

22. Lee M, Sousa MC. Structural Basis for Substrate Speci fi city in Arn B. A Key Enzyme in the Polymyxin Resistance Pathway of Gram-Negative Bacteria. Biochem 2014,. 2014;53(Figure 1):796805.

23. Soon RL, Nation RL, Hartley PG, Larson I, Li J. Atomic Force Microscopy Investigation of the Morphology and Topography of ColistinHeteroresistant Acinetobacter baumannii Strains as a Function of Growth Phase and in Response to Colistin Treatment. 2009;53(12):4979-86.

24. Drali R, Berrazeg M, Zidouni LL, Hamitouche F, Abbas AA, Deriet A, Mouffok F. Emergence of mcr-1 plasmid-mediated colistin-resistant Escherichia coli isolates from seawater. Science of the total environment. 2018 Nov 15;642:90-4.

25. Carattoli A. Plasmids and the spread of resistance. Int J Med Microbiol. 2013;303:298-304.

26. Dortet L, Bonnin R, Jousset A, Gauthier L, Naas $\mathrm{T}$. Émergence de la résistance à la colistine chez les entérobactéries : une brèche dans le dernier rempart contre la pan-résistance ! J des Antiinfectieux. 2016;18(4):139-59.

27. Bianco F Del, Morotti M, Pedna MF, Farabegoli P, Sambri V. Microbiological surveillance of plasmid mediated colistin resistance in human Enterobacteriaceae isolates in Romagna (Northern Italy): August 2016 - July 2017. Int J Infect Dis. 2018;69:96-8.

28. Bouchenak O, Yahiaoui K, Benhabyles N, Laoufi R, Arab K. Etude pytochimique et évaluation de l'activité antimicrobienne de deux variétés de l'olivier. 2018;(July):13-21.

29. Cushnie T, Lamb A. Recent advances in understanding the antibacterial properties of flavonoïds. Intern J Antimicrob Agents. 2011;38(2):99-107.

30. Wu T, He M, Zang X, Zhou Y, Qiu T, Pan S, Xu $X$. A structure-activity relationship study of flavonoids as inhibitors of $E$. coli by membrane interaction effect. Biochimica et Biophysica Acta (BBA)-Biomembranes. $2013 \quad$ Nov 1;1828(11):2751-6.

31. Dougnon Tossou J, Adéhan S, Houessionon J, Farougou S. In Vitro effect of the ethanolic extract of Tephrosia Vogelii on Rhipicephalus Sanguineus in Abomey-Calavi. AJP. 2015;5(3):247-59.

32. Kabera J, Tuyisenge R, Ugirinshuti V, Nyirabageni A, Munyabuhoro S. Preliminary investigation on anthelmintic activity and phytochemical screening of leaf crude extracts of Tithonia diversifolia and Tephrosia Vogelii. 2014;8(25):2449-57.

33. Ghedadba N, Hambaba L, Ayachi A, Aberkane MC, Bousselsela H, Oueld-Mokhtar SM. Polyphénols totaux, activités antioxydante et antimicrobienne des extraits des feuilles de Marrubium deserti de Noé. Phytothérapie. 2015;112.

34. Kassah Laoure H, Khenioua S. Etude quantitative et qualitative des composés phénolique chez quatre variétés de blé tendre (Triticum aestivium) et d'orge (Hordeum vulgare) soumises à un stress hydrique et leurs activités antimicrobiénnes. Constantine; 2015.

35. Breilh D. Optimisation de l'antibiothérapie. Le Pharmacien Hospitalier et Clinicien.2013, 48 :5363.

36. Haoulia A. Tests phytochimiques, dosage et recherche d'effet hémolytique des polyphénols totaux extraits de la partie aérienne d'Ammoïdes verticillata. 2015.

37. Wanga $\mathrm{B}$, Akenga $\mathrm{T}$, Imbuga $\mathrm{M}$, Gitonga $\mathrm{L}$, Olubayo F, Namungu P. Antimicrobial acitivity of extracts from Tephrosia Vogelii Hook F. J Agric Sci Technol. 2006;8(1):4-5.

38. Couriera M. Etude in vitro de la potentialisation d'antibiotiques contre des souches d' $E$. coli O78K80 multirésistantes isolées en élévage aviaire par les huiles essentielles. 2017.

39. Chanda S, Rakholiya K. Combination therapy: Synergism between natural plant extracts and antibiotics against infectious diseases. Microbiol Book Series. 2011:520-9.

40. Ngoua-Meye-Misso RL, Sima-Obiang C, Ndong JD, Ondo JP, Ovono Abessolo F, Obame-Engonga LC. Phytochemical screening, antioxidant, antiinflammatory and antiangiogenic activities of Lophira procera A. Chev.(Ochnaceae) medicinal plant from Gabon. Egyptian Journal of Basic and Applied Sciences. 2018 Mar 1;5(1):80-6. 